medRxiv preprint doi: https://doi.org/10.1101/2021.04.16.21255595; this version posted April 16, 2021. The copyright holder for this preprint (which was not certified by peer review) is the author/funder, who has granted medRxiv a license to display the preprint in perpetuity.

All rights reserved. No reuse allowed without permission.

\title{
Software development for Autologous Skin substitute production
}

Guillaume Mestrallet

Université Paris-Saclay, Paris, France

\section{*Corresponding Author}

guillaume.mestrallet@agroparistech.fr

Conflicts of Interest: the author declares no conflicts of interest. 
medRxiv preprint doi: https://doi.org/10.1101/2021.04.16.21255595; this version posted April 16, 2021. The copyright holder for this preprint (which was not certified by peer review) is the author/funder, who has granted medRxiv a license to display the preprint in perpetuity.

\begin{abstract}
The gold-standard for the management of patients affected by large-surface third-degree burns is autologous skin graft. When burns affect $<40 \%$ total body surface area (TBSA), meshed skin samples harvested from non-affected donor sites can be used as grafts. In more severe cases corresponding to burns affecting $>40 \%$ TBSA), the donor site surfaces are insufficient. The alternative grafting strategy uses bioengineered skin substitutes that are generated using the own keratinocytes of the patient after ex vivo expansion. Optimal setup of the bioengineering process involved determination of the required graft surface, adjustment of cell quantities, and control of the timing necessary for production. Accordingly, tools to assist the design of personalized protocols will certainly contribute to care quality and cost limitation. Here, I describe the principle of a software-assisted calculation of the required graft surface and keratinocyte numbers needed, according to specific patient clinical characteristics. The software also offers assistance to estimate the Baux score, a method that has been proposed to link the severity of burn injuries and the prognosis for the patient. In conclusion, this software provides a principle of assisted burned patient diagnose and skin substitute bioengineering process which development may facilitate the design of personalized protocols for skin regenerative cell therapies.
\end{abstract}

\title{
KEY WORDS
}

Software, skin graft, skin substitute, bioengineering, keratinocytes, burns 
medRxiv preprint doi: https://doi.org/10.1101/2021.04.16.21255595; this version posted April 16, 2021. The copyright holder for this preprint (which was not certified by peer review) is the author/funder, who has granted medRxiv a license to display the preprint in perpetuity.

\section{INTRODUCTION}

According to the World Health Organization, burns cause 180,000 deaths a year and more than 30,000,000 cases require hospital treatment in the world in 2018 [1]. Norway is one of the few countries that made public its data on the treatment of burns in 2007. Information from the Norwegian patient registry reveals that a total of 726 patients were admitted to hospitals for acute burns, representing an incidence rate of 15.5 / 100,000 inhabitants for one year [2]. In Norway, the costs of hospital burn treatment in 2007 exceeded 10.5 million euros. The rate of burns requiring hospitalization in children under 5 years was 5.3 times higher or $82.5 / 100,000$ inhabitants per year. The average age of all burn patients was 26.9 years, twothirds of them being men with an average hospital stay of 11.3 days. Fifteen of the patients (2.1\%) died of burns in Norwegian hospitals that year. The management of burned patients is still challenging in the $21^{\text {st }}$ century.

The therapeutic arsenal includes split thickness and full thickness skin grafts, when donor sites are available in a sufficient quality and quantity to cover burns [3]. In the context of largesurface burns, the therapeutic option consists in grafting bioengineered skin substitutes generated using patient's keratinocytes that are massively amplified ex vivo to reach required material quantities [4], [5]. Notably, this principle has been combined with viral vectormediated gene therapy to successfully treat epidermolysis bullosa skin [6], [7]. In skin bioengineering protocols, keratinocytes are extracted from small-size skin biopsies (often 2 or $4 \mathrm{~cm}^{2}$ ) harvested from intact tissue areas, often the groin or armpits (Figure 1). Keratinocytes are then amplified for 1 to 3 weeks in bidimensional culture, and then used to generate a threedimensional sheet [8], [9]. The culture conditions used for keratinocyte amplification originate from the Green's pioneering work in 1979 [10]. Current processes still use serum and growtharrested feeder fibroblasts to promote keratinocyte expansion [9].

This technology has proved efficiency to save patient's lives, as clinical trials have been successfully conducted during the last three decades [8]. For example, one of these included 63 patients and reported a transplant take rate of $65 \%$, with a patient survival rate of $84 \%$ after 7 days. The reported infection rate was $4.3 \%$, and $11 \%$ of the patients had received a second transplantation procedure [11]. A second one included 88 patients and reported a transplant take rate of $72.7 \%$, with a patient survival rate of $91 \%$ [12]. Recently, ten pediatric patients with skin defects were included in a clinical study[13]. Skin grafts of $49 \mathrm{~cm}$ were bioengineered using autologous keratinocytes and fibroblasts isolated from a $4 \mathrm{~cm}^{2}$ patient's skin biopsy and 
medRxiv preprint doi: https://doi.org/10.1101/2021.04.16.21255595; this version posted April 16, 2021. The copyright holder for this preprint (which was not certified by peer review) is the author/funder, who has granted medRxiv a license to display the preprint in perpetuity.

All rights reserved. No reuse allowed without permission.

then incorporated in a collagen hydrogel. In this phase 1study, safe coverage of skin defects was achieved.

The clinician calculates the Total Burn Surface Area (TBSA) in the second and third degree. The percentage of the total burned surface of the body to which each zone corresponds is calculated according to age, with the rule of Wallace or that of Lund and Browder [15]-[17]. Software development will automate and make more rigorous these calculations, thus allowing a better diagnosis. This work is a proof of principle established from data published in the literature [7], [9].

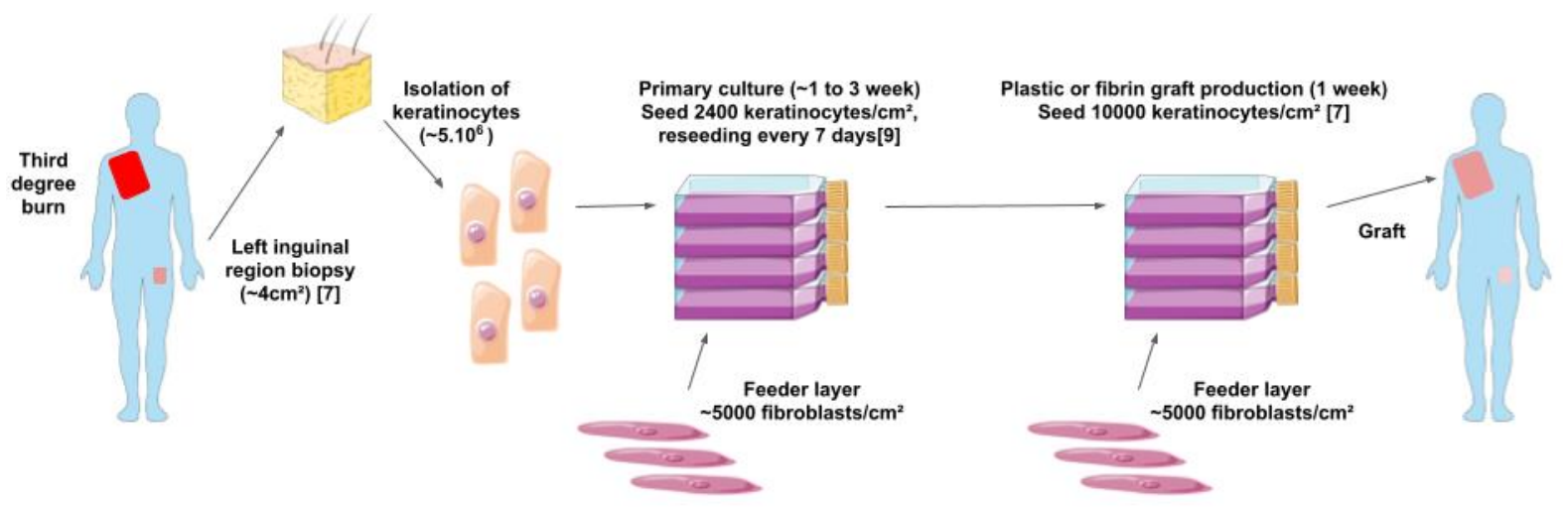

\section{Figure 1: Bioengineering of an epidermal graft}

Keratinocytes are obtained from 2 to $4 \mathrm{~cm}^{2}$ skin biopsies from healthy areas that heal well and have little exposure, such as the groin and armpits [6], [8]. Keratinocytes are seeded at 2400 keratinocytes $/ \mathrm{cm}^{2}$ and preamplified for 1 to 3 weeks in sheets [9].Then, keratinocytes are seeded at 10000 keratinocytes $/ \mathrm{cm}^{2}$, amplified and transferred onto a sterile gauze that will then be deposited on the area to be treated after 7 more days [7]. Keratinocytes are amplified with a feeder layer of fibroblasts, in serum containing medium. 
medRxiv preprint doi: https://doi.org/10.1101/2021.04.16.21255595; this version posted April 16, 2021. The copyright holder for this preprint (which was not certified by peer review) is the author/funder, who has granted medRxiv a license to display the preprint in perpetuity.

\section{METHODS}

The software only allows clinicians registered with the authors to have access to medical records, in order to avoid misuse of the data. The software can be used on a computer or on a mobile phone. Communication between the server and users was done via the Hypertext Transfer Protocol (HTTP) and an Application Programming Interface (API) specific to this application". The protection of personal data, with the new European GDPR legislation, aims to protect patient data. The security issue of storing patient data online, and respecting medical secrecy, is the responsibility of the clinician. One solution would be to store this data on hospital servers in connection with the patient's computerized medical record [22]. Once connected, the clinician can either diagnose a new patient or access the diagnosis of a registered patient by indicating their first or last name. In Table 1 are referenced the questions allowing to diagnose the patient via the form.

\section{Table 1: Patient information collected by form}

-What is the patient's first name?

-What is the patient's name?

-What is the date of birth?

-What is the weight of the patient (in $\mathrm{kg})$ ?

-What is the patient height (in $\mathrm{cm})$ ?

-Is there an inhalation injury (yes/no)?

-Indicate the percentage (between 0 and 100) of the head and neck that is affected in the $2^{\text {nd }}$ degree.

-Indicate the percentage (between 0 and 100) of the head and neck that is affected in the $3^{\text {rd }}$ degree.

-Indicate the percentage (between 0 and 100) of the anterior face of the trunk which is affected in the $2^{\text {nd }}$ degree. 
medRxiv preprint doi: https://doi.org/10.1101/2021.04.16.21255595; this version posted April 16, 2021. The copyright holder for this preprint (which was not certified by peer review) is the author/funder, who has granted medRxiv a license to display the preprint in perpetuity.

-Indicate the percentage (between 0 and 100) of the anterior surface of the trunk which is affected in the $3^{\text {rd }}$ degree.

-Indicate the percentage (between 0 and 100) of the posterior surface of the trunk which is affected in the $2^{\text {nd }}$ degree.

-Indicate the percentage (between 0 and 100) of the posterior surface of the trunk which is affected in the $3^{\text {rd }}$ degree.

-Indicate the percentage (between 0 and 100) of the upper limbs that is affected in the $2^{\text {nd }}$ degree.

-Indicate the percentage (between 0 and 100) of the upper limbs that is affected in the $3^{\text {rd }}$ degree.

-Indicate the percentage (between 0 and 100) of the lower limbs that is affected in the $2^{\text {nd }}$ degree.

-Indicate the percentage (between 0 and 100) of the lower limbs that is affected in the $3^{\text {rd }}$ degree.

-Indicate the percentage (between 0 and 100) of the external genital organs that is affected in the $2^{\text {nd }}$ degree.

-Indicate the percentage (between 0 and 100) of the external genitalia that is affected in the $3^{\text {rd }}$ degree.

The clinician calculates the Total Burn Surface Area (TBSA) in the second and third degree. In accordance with current clinical standards, these areas are the head and neck, the lower limbs, the upper limbs, the external genitalia, the posterior surface of the trunk and the anterior surface of the trunk. However, the percentage of the total area of the body that these different areas represent varies depending on the age of the patient. Informing the patient's age therefore allows these different areas to be assigned an appropriate value. Each value represents a percentage of the total body surface area based on the age of the patient. The calculation of the total area of the patient's body from his weight and height is done using the Du Bois formula [14]. 
medRxiv preprint doi: https://doi.org/10.1101/2021.04.16.21255595; this version posted April 16, 2021. The copyright holder for this preprint (which was not certified by peer review) is the author/funder, who has granted medRxiv a license to display the preprint in perpetuity.

\section{$\mathrm{BSA}=\mathbf{0 . 0 0 7 1 8 4} \times \mathrm{W}^{0.425} \times \mathrm{H}^{0.725}$}

With BSA = Body Surface Area in $\mathrm{m}^{2}, \mathrm{~W}=$ weight in $\mathrm{kg}$ and $\mathrm{H}=$ height in $\mathrm{cm}$.

Once the form has been completed, the software calculates the variables in Table 2 and displays the patient's diagnosis.

\begin{tabular}{|c|}
\hline -total area of the patient $b$ \\
\hline -total area of the patient $b$ \\
\hline $\begin{array}{l}\text {-total area of the patient } b \\
\text { total body area) }\end{array}$ \\
\hline -Graft surface to prepare \\
\hline -Surface of the biopsy to \\
\hline -Duration of amplification \\
\hline -Graft preparation protoce \\
\hline -Baux score \\
\hline -Probability of death (\%) \\
\hline
\end{tabular}

The percentage of the total surface of the body to which each zone corresponds is calculated as in Table 3, according to age, with the rule of Wallace or that of Lund and Browder [15]-[17]. 


\begin{tabular}{|l|c|c|c|c|}
\hline Table 3: Assessment of the burned area as a function of age \\
\hline & \multicolumn{4}{|c|}{ Age (years) } \\
\hline & $0-4$ & $5-9$ & $10-15$ & $>15$ \\
\hline Head and neck & $21 \%$ & $15 \%$ & $12 \%$ & $9 \%$ \\
\hline Anterior face of the trunk & $13 \%$ & $13 \%$ & $13 \%$ & $18 \%$ \\
\hline Posterior surface of the trunk & $18 \%$ & $18 \%$ & $18 \%$ & $18 \%$ \\
\hline Upper limbs & $19 \%$ & $19 \%$ & $19 \%$ & $18 \%$ \\
\hline Lower limbs & $28 \%$ & $34 \%$ & $37 \%$ & $36 \%$ \\
\hline External genital organs & $1 \%$ & $1 \%$ & $1 \%$ & $1 \%$ \\
\hline
\end{tabular}

The size of the graft to be prepared is calculated by summing the burned areas in the third degree. The size of the skin biopsy to be taken and the graft preparation protocol is determined by previous clinical observations [7]. Keratinocytes have a high proliferation rate and grow through a total of 20 to 50 generations depending on the age of human donor, 20 generations correspond to an increase in cell mass of approximately 106-fold [18]. From a single $\mathrm{cm}^{2}$ of biopsy of healthy tissue, it is possible to extract $1,000,000$ to $4,000,000$ keratinocytes depending on the age and anatomic site [7]. The choice was made to fix the maximum size of the sample at $4 \mathrm{~cm}^{2}$ to avoid unduly altering the unaffected areas of the patient.

Thus, keratinocytes are obtained from 2 to $4 \mathrm{~cm}^{2}$ skin biopsies from healthy areas that heal well and have little exposure, such as the groin and armpits [6], [8]. Keratinocytes are amplified for 1 to 3 weeks with successive passages every 7 days. Keratinocytes are amplified with a feeder layer of fibroblasts, in serum containing medium. There is a period of amplification of the cells ex vivo, followed by a period of preparation of the graft, with different seeding densities. The seeding densities for these two periods are referenced in Figure $\mathbf{1}$ and are taken from previous studies [7]. In this last publication, $3 \times 10^{7}$ keratinocytes provide $2880 \mathrm{~cm}^{2}$ in 7 days with fibrin. 
medRxiv preprint doi: https://doi.org/10.1101/2021.04.16.21255595; this version posted April 16, 2021. The copyright holder for this preprint (which was not certified by peer review) is the author/funder, who has granted medRxiv a license to display the preprint in perpetuity.

All rights reserved. No reuse allowed without permission.

It is therefore necessary to inoculate 10417 keratinocytes for 7 days on fibrin in order to have $1 \mathrm{~cm}^{2}$ of skin. This figure is here rounded to 10,000 . For the preamplification phase, keratinocytes are thawed and plated at 2,400 cells per $\mathrm{cm} 2$ [9]. The production time is calculated based on the size of the burned area. If the number of cells required for seeding for graft production is less than or equal to the number of cells obtained from the biopsy, the production time is 7 days. If the number of cells necessary for the seeding for graft production is between the number of cells obtained from the biopsy and the number of cells that can be obtained at most after 7 days of amplification, the production time is 14 days. If it is higher, the production time is 21 days.

The number of cells needed to prepare the graft and the size of the biopsy to be taken to obtain them depends on the preparation time of the graft chosen. I define two new formulas to calculate them.

\section{TNCR $=$ GZ $\times$ FNC $/$ GRC7 $^{\text {AT-1 }}$}

With TNCR $=$ total number of cells required for the first amplification during the first 7 days, $\mathrm{GZ}=$ graft size $\left(\mathrm{cm}^{2}\right), \mathrm{FNC}=$ Final number of cells to seed per $\mathrm{cm}^{2} 7$ days before grafting. At this stage, 7 days before the transplant, it goes from cell amplification to graft production. GRC7 = growth rate of cells in 7 days (average number of cells obtained from a single cell), $\mathrm{AT}=$ amplification time (weeks). 
medRxiv preprint doi: https://doi.org/10.1101/2021.04.16.21255595; this version posted April 16, 2021. The copyright holder for this preprint (which was not certified by peer review) is the author/funder, who has granted medRxiv a license to display the preprint in perpetuity.

\section{$\mathbf{B Z}=\mathbf{T N C R} / \mathbf{B C Y}$}

With $\mathrm{BZ}=$ biopsy size $\left(\mathrm{cm}^{2}\right), \mathrm{BCY}=$ biopsy cell yield (number of cells extracted from a biopsy $\left.\mathrm{cm}^{2}\right)$. Here FNC is equal to 10,000 cells $/ \mathrm{cm}^{2}$, GRC7 of keratinocytes is equal to 17 cells and $\mathrm{BCY}$ is equal to $1,250,000$ cells $/ \mathrm{cm}^{2}[7]$.

Finally, the revised Baux score for mortality prediction in burns patients has been adopted [19].

\section{Baux Score $=$ A $+\%$ TBSA}

With $\mathrm{A}=$ Age in years, \% TBSA = Percentage of Total Body Surface Area burned (between 0 and 100).

Probability of mortality $=100 \times\left(\mathrm{e}^{-8.8163}+(0.0775 \times\right.$ Revised Baux Score $\left.)\right) /\left(1+\mathrm{e}^{-8.8163}+(0.0775 \times\right.$ Revised Baux Score)

With Revised Baux Score $=$ Baux Score +17 if there is an inhalation injury.

\section{RESULTS}

The results of Figure 2 are obtained by fixing the amplification and production parameters according to previous studies (see introduction and methods) and by varying the amplification time between 7, 14 and 21 days. Here I take the values drawn from the work of the De Luca team [7] and Percy hospital [9]. AT varies from 1 to 3 weeks. As can be seen, an amplification of a single week can produce a graft of sufficient size only if the surface to be grafted is very 
medRxiv preprint doi: https://doi.org/10.1101/2021.04.16.21255595; this version posted April 16, 2021. The copyright holder for this preprint (which was not certified by peer review) is the author/funder, who has granted medRxiv a license to display the preprint in perpetuity. All rights reserved. No reuse allowed without permission.

small $\left(<500 \mathrm{~cm}^{2}\right)$. Indeed, it would otherwise be necessary to carry out a too large biopsy, incompatible with the patient's survival. Likewise, an amplification of 2 weeks only makes it possible to produce a graft of sufficient size if the surface to be grafted is not too large in size $\left(<8,500 \mathrm{~cm}^{2}\right)$. On the other hand, an amplification of 3 weeks makes it possible to produce a graft of a size sufficient to cover an entirely burned patient $\left(\sim 20,000 \mathrm{~cm}^{2}\right)$ from a biopsy of less than one $\mathrm{cm}^{2}$. However, waiting so long may be incompatible with patient survival.
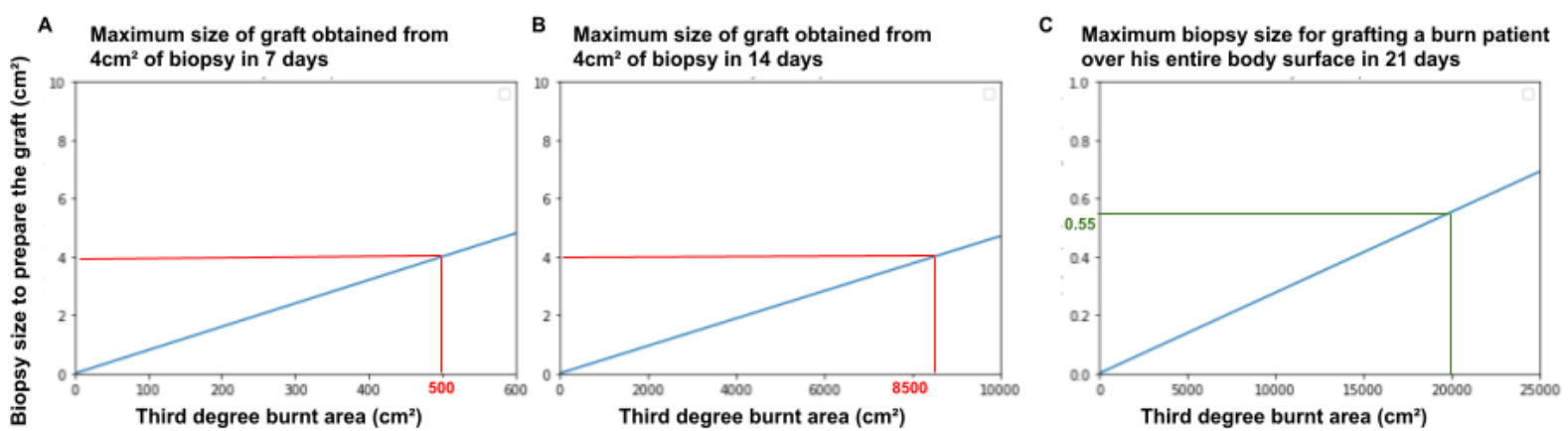

Figure 2: Calculation of the biopsy size to prepare the graft, according to the amplification time.

Calculation of the biopsy size $\left(\mathrm{cm}^{2}\right)$ to produce a graft of sufficient size, according to the duration of amplification (weeks). A : 1 week, B : 2 weeks, C : 3 weeks.

$\mathrm{BZ}=\mathrm{GZ} \times \mathrm{FNC} /\left(\mathrm{GRC} 7^{\mathrm{AT}-1} \times \mathrm{BCY}\right)$

With GZ $=$ graft size $\left(\mathrm{cm}^{2}\right), \mathrm{FNC}=$ Final number of cells to seed per $\mathrm{cm}^{2} 7$ days before grafting, GRC7 $=$ growth rate of cells in 7 days (average number of cells obtained from a single cell), $\mathrm{AT}=$ amplification time (weeks), $\mathrm{BZ}=$ biopsy size $\left(\mathrm{cm}^{2}\right), \mathrm{BCY}=$ biopsy cell yield (number of cells extracted from a biopsy $\mathrm{cm}^{2}$ ).

The software makes it possible to determine graft preparation scenarios according to the area burned in the third degree and therefore the size of the graft to be prepared. They are presented in Table 4. These scenarios are characterized by the size of the graft, the duration of its 
medRxiv preprint doi: https://doi.org/10.1101/2021.04.16.21255595; this version posted April 16, 2021. The copyright holder for this preprint (which was not certified by peer review) is the author/funder, who has granted medRxiv a license to display the preprint in perpetuity.

preparation and the size of the biopsy of healthy tissue to be taken from the patient. I chose to limit the size of the biopsy to $4 \mathrm{~cm}^{2}$ to avoid unduly altering the unaffected areas of the patient [7].

Table 4 : Graft preparation scenarios calculated by the software

\begin{tabular}{|l|c|c|c|}
\hline Third degree burned area $\left(\mathrm{cm}^{2}\right)$ & $\mathrm{x}<500$ & $500<\mathrm{x}<8500$ & $8500<\mathrm{x}<144500$ \\
\hline Graft preparation time (days) & 12 & 21 & 28 \\
\hline Size of biopsy to be taken $\left(\mathrm{cm}^{2}\right)$ & $<4$ & 4 & 4 \\
\hline
\end{tabular}

In the case of a third degree burned surface of less than $500 \mathrm{~cm}^{2}$, it is not necessary to take more than $4 \mathrm{~cm}^{2}$ of tissue and the graft can be prepared in 12 days. The keratinocytes must be extracted from the biopsy and amplified in co-culture with a feeder layer of fibroblasts according to current clinical protocols. In the case of a third degree burned area between $500 \mathrm{~cm}^{2}$ and $8,500 \mathrm{~cm}^{2}, 4 \mathrm{~cm}^{2}$ of tissue must be removed and the graft can be prepared in $\sim 20$ days. It is necessary to extract the keratinocytes from the biopsy and to amplify them in coculture with a feeder layer of fibroblasts according to current clinical protocols for 12 days, trypsinize the cells from the initial cell culture flasks and re-amplify them 7 days after seeding them a the appropriate density. In the case of a third degree burned surface greater than $8,500 \mathrm{~cm}^{2}$, the same procedure must be followed, adding another 7 days of amplification. The total body surface of an adult human is approximately $2 \mathrm{~m}^{2}\left(20,000 \mathrm{~cm}^{2}\right)$ so the preparation of the graft does not require more than 28 days in the worst case.

The software considers these different scenarios to select the one that is the most suitable. In Figure 3, there is an example of the data collection of a fictitious patient carried out by a clinician as described in the methods section. These data are processed and saved in the database to allow the clinician to find them later if necessary. 
medRxiv preprint doi: https://doi.org/10.1101/2021.04.16.21255595; this version posted April 16, 2021. The copyright holder for this preprint (which was not certified by peer review) is the author/funder, who has granted medRxiv a license to display the preprint in perpetuity.

All rights reserved. No reuse allowed without permission.

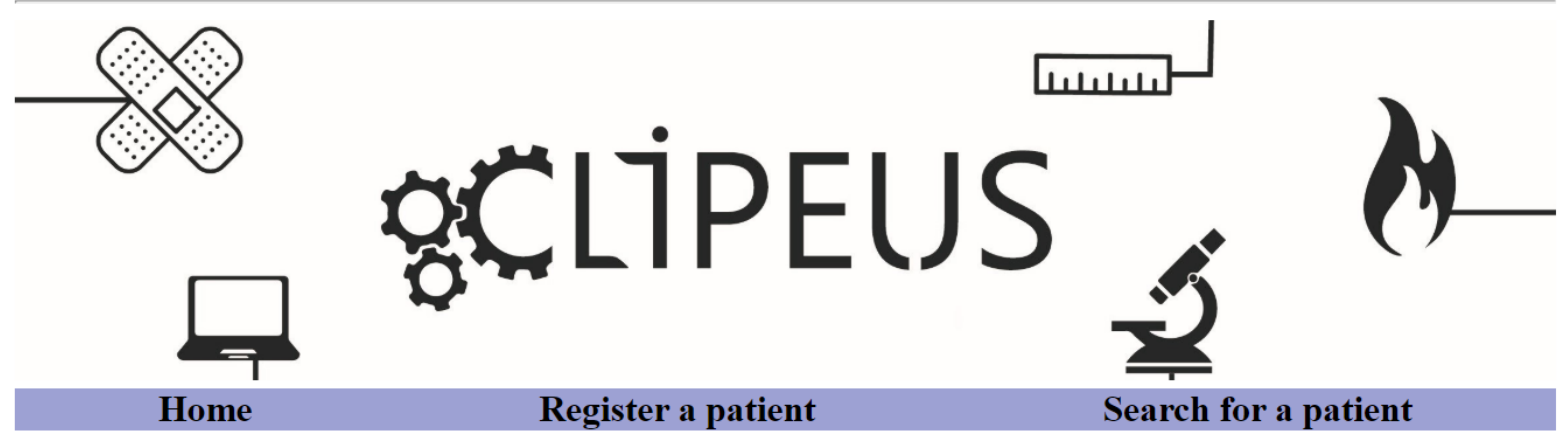

\section{Please enter the patient's characteristics :}

First name: joe

Last name: smith

Gender (male/female): male

Age (in years): 35

Weight (in $\mathrm{kg}): 80$

Height (in cm): 180

Presence of inhalation injury.

Indicate the percentage (between 0 and 100) of the head and neck which is burned in the second degree. 5

Indicate the percentage (between 0 and 100) of the head and neck which is burned in the third degree. 85

Indicate the percentage (between 0 and 100) of the anterior side of the trunk which is burned in the second degree. 10

Indicate the percentage (between 0 and 100) of the anterior side of the trunk which is burned in the third degree. 80

Indicate the percentage (between 0 and 100) of the posterior side of the trunk which is burned in the second degree. 5

Indicate the percentage (between 0 and 100) of the posterior side of the trunk which is burned in the third degree. 70

Indicate the percentage (between 0 and 100) of upper limbs burned in the second degree. 15

Indicate the percentage (between 0 and 100) of upper limbs burned in the third degree. 75

Indicate the percentage (between 0 and 100) of the lower limbs that is burned in the second degree. 10

Indicate the percentage (between 0 and 100 ) of the lower limbs that is burned in the third degree. 80

Indicate the percentage (between 0 and 100) of external genitals that is burned in the second degree. 0

Indicate the percentage (between 0 and 100) of external genitals that is burned in the third degree. 0

Date of diagnosis: 2020-10-21 17:00:21

Submit

\section{Figure 3: Burned patient data collection form.}

Example of the data collection from a fictitious patient by a clinician as described in the methods section. 
medRxiv preprint doi: https://doi.org/10.1101/2021.04.16.21255595; this version posted April 16, 2021. The copyright holder for this preprint (which was not certified by peer review) is the author/funder, who has granted medRxiv a license to display the preprint in perpetuity.

All rights reserved. No reuse allowed without permission.

In Figure 4, there is an example of a fictitious patient diagnosis by the software as described in the methods section. The fictitious patient is therefore in the situation corresponding to the second scenario in Table 4. His probability of mortality is $66 \%$ but it takes 21 days to produce the graft from a $4 \mathrm{~cm}^{2}$ biopsy. The size of the graft to be produced corresponds to the third degree burned area, which is $15363 \mathrm{~cm}^{2}$ here. The graft production protocol is then described with the number of cells required for each step.
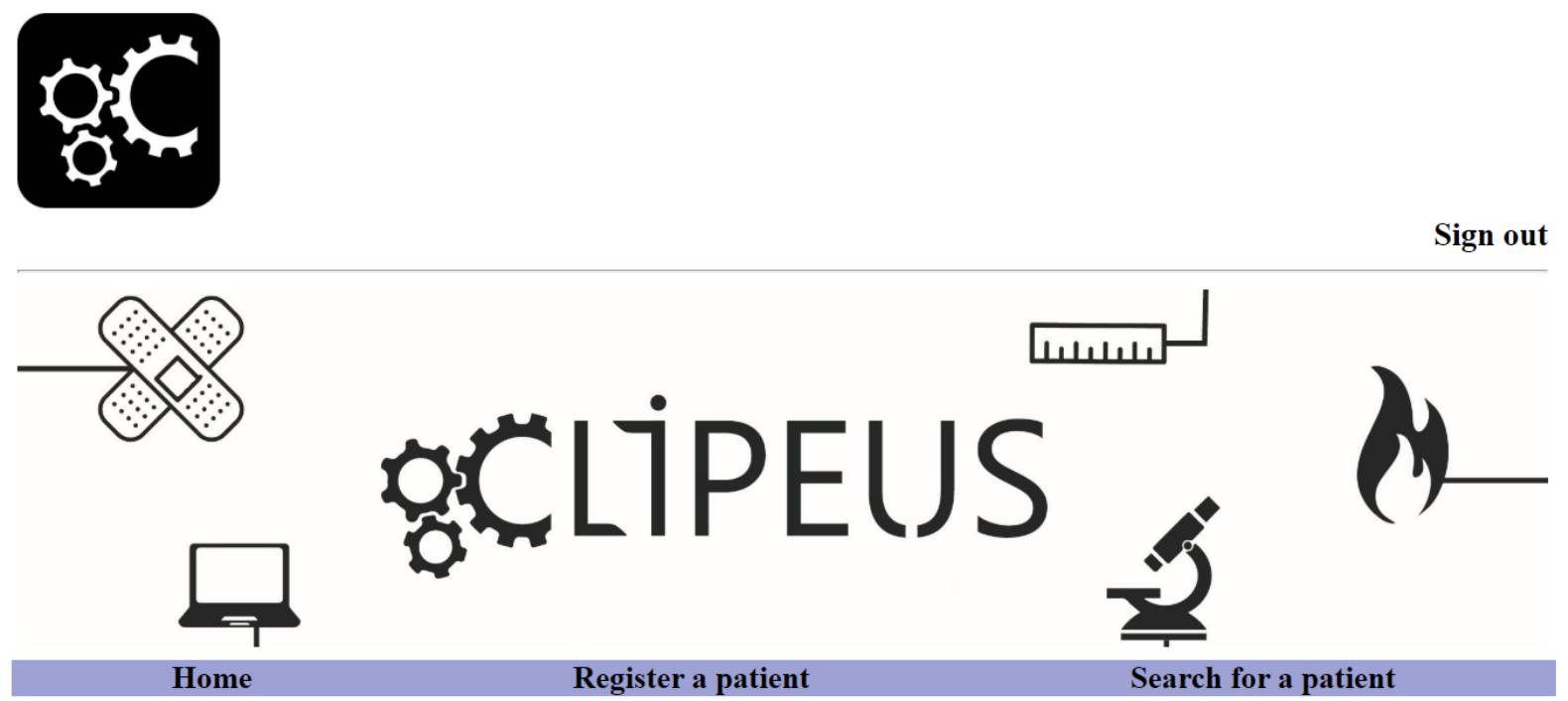

\section{Here is the diagnostic of the patient joe smith :}

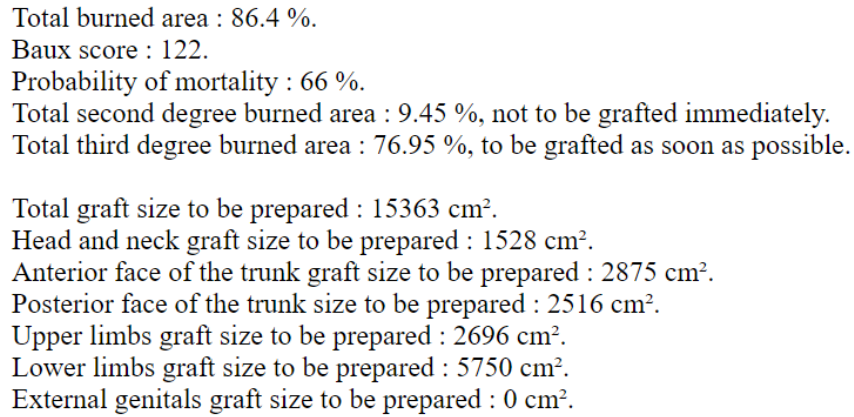

To obtain this graft, the following protocol must be followed : It is necessary to take $4 \mathrm{~cm}^{2}$ of biopsy and seed 5000000 keratinocytes, at a density of 2400 keratinocytes $/ \mathrm{cm}^{2}$ on plastic flasks and to cultivate them 7 days. Then you have to do the same with 85000000 keratinocytes for 7 days. Finally, you have to seed 168993001 keratinocytes, at a density of 10000 keratinocytes $/ \mathrm{cm}^{2}$ on fibrin or in plastic flasks and cultivate them for 7 days. This allows the graft to be obtained after 21 days.

\section{Figure 4: Diagnosis of the burned patient.}

Example of the diagnosis of a fictitious patient calculated by the software as described in the methods section. 
medRxiv preprint doi: https://doi.org/10.1101/2021.04.16.21255595; this version posted April 16, 2021. The copyright holder for this preprint (which was not certified by peer review) is the author/funder, who has granted medRxiv a license to display the preprint in perpetuity.

\section{DISCUSSION}

Few quantitative methods are reported in the literature to adjust the cell quantities necessary in view of skin substitute production according to specific patient characteristics. No automation and quantification allowing diagnosis are proposed. One rare quantitative approach using Matlab computing language is tensor decomposition for color image segmentation of burn wounds [20]. The aim is to use a new automated segmentation of the images in order to determinate the burn area. An issue would be to investigate the segmentation of burn areas on 3D images to include curves and depth to further improve the segmentation accuracy.

The software developed here enables segmentation of the burned areas to be treated as a priority. By automating the calculation of the area to be transplanted in the patient, the duration of preparation of the graft and the quantity of cells required, it allows the clinician to plan the treatment more reliably. By defining two new formulas to calculate the number of cells required to prepare the graft and consequently the size of the associated biopsy, it makes it possible to prepare a graft in a more precise time with the least possible materials and costs. The software proposes three different bioengineering scenarios in two, three or four weeks (Table 4), which can help the clinician to predict the patient's treatment time and the length of hospital stay. According to the data from the 2007 Norwegian patient registry, the average total cost of treating a patient with hospital burns is around $14463 €$, which corresponds to $1280 €$ per night [2]. The use of this software can help to better calculate the time spent by the patient in the hospital. Its use could therefore save $1280 €$ per night and per patient in the event of overestimation of the duration of graft preparation.

In case of a deep burn in the hand ( $80 \%$ of cases), there are therapeutic alternatives to excisiongrafting [21]. These are artificial dermis (Alloderm, Matriderm, Integra) and flaps. In the presence of immediately usable donor areas, the combination Matriderm / full thin skin graft 
medRxiv preprint doi: https://doi.org/10.1101/2021.04.16.21255595; this version posted April 16, 2021. The copyright holder for this preprint (which was not certified by peer review) is the author/funder, who has granted medRxiv a license to display the preprint in perpetuity.

is recommended. However, these techniques are expensive. The Integra ${ }^{\circledR}$ (artificial dermis) costs between 5 and $5.5 €$ per $\mathrm{cm}^{2}$, the Matriderm ${ }^{\circledR}$, between 4 and $5 €$ per $\mathrm{cm}^{2}$, while the Alloderm is even more expensive $\left(32 € 50\right.$ per $\left.\mathrm{cm}^{2}\right)$. Moreover, there is always a need to best estimate the size of the graft, so the program developed here is also useful in these cases. Take the case of an adult with third degree burns on $10 \%$ of the upper limbs. His total body surface area is approximately $2 \mathrm{~m}^{2}$. An overestimation of $10 \%$ of the size of the burn, and therefore of the size of the commercial graft to be ordered, can lead to an additional cost of 36 to $360 €$. Today, although the technology for producing autografts is not new, there is no way to accurately assess burned areas and predict the number of cells necessary to produce the graft. Developing a skin substitute with the help of softwares to estimate accurately the needs would optimize the whole process. The new software presented here is the first one to better automate the evaluation of burn size and that of the graft to be prepared. It is also the first to calculate the number of cells and the duration necessary for the graft production, as well as the size of the biopsy of healthy tissue to be taken, the Baux score and the probability of mortality. The limitation of this software is the differences in cell quality for skin regeneration between various donors, due to interindividual variations, well known in the cellular biology scientist's community. This software therefore brings progress towards more precise determination of the treatment conditions of severely burned patients.

\section{ACKNOWLEDGEMENTS}

The author thanks Alexandre Pierga for the visual elements of the software, Clément Hénin and Louis-Gabriel Mognetti for their contribution to technical aspects of the software, and Dr Lellouch for for clinic-related discussions. This research did not receive any specific grant from funding agencies in the public, commercial, or not-for-profit sectors. 


\section{ABBREVIATIONS}

A - Age

API - Application Programming Interface

AT - amplification time

BCY - biopsy cell yield (number of cells extracted from a biopsy $\mathrm{cm}^{2}$ )

BSA - Body Surface Area

BZ - Biopsy Size

GRC7 - Growth Rate of Cells in 7 days (average number of cells obtained from a single cell)

GZ - Graft Size

$\mathrm{H}$ - Height

HTTP - Hypertext Transfer Protocol

FNC - Final number of cells to seed per $\mathrm{cm}^{2} 7$ days before grafting

STSG - Split Thickness Skin Graft

TBSA - Total Body Surface Area

TNCR - Total Number of Cells Required

WHO - World Health Organization

W - Weight

\%TBSA - Percentage of Total Body Surface Area burned

\section{REFERENCES}

[1] World Health Organization, « Burns », Burns World Health Organization, 2018. https://www.who.int/news-room/fact-sheets/detail/burns (consulté le déc. 16, 2020).

[2] H. Onarheim, S. A. Jensen, B. E. Rosenberg, et A. B. Guttormsen, « The epidemiology of patients with burn injuries admitted to Norwegian hospitals in 2007 », Burns J. Int. Soc. Burn Inj., vol. 35, nº 8, p. 1142-1146, déc. 2009, doi: 10.1016/j.burns.2009.06.191.

[3] G. G. Gallico, N. E. O'connor, C. C. Compton, O. Kehinde, et H. Green, « Permanent Coverage of Large Burn Wounds with Autologous Cultured Human Epithelium », N. Engl. J. Med., vol. 311, nº 7, p. 448-451, août 1984, doi: 10.1056/NEJM198408163110706. 
medRxiv preprint doi: https://doi.org/10.1101/2021.04.16.21255595; this version posted April 16, 2021. The copyright holder for this preprint (which was not certified by peer review) is the author/funder, who has granted medRxiv a license to display the preprint in perpetuity.

[4] G. Pellegrini et al., « The control of epidermal stem cells (holoclones) in the treatment of massive full-thickness burns with autologous keratinocytes cultured on fibrin», Transplantation, vol. 68, n 6 , p. 868-879, sept. 1999.

[5] V. Ronfard, J. M. Rives, Y. Neveux, H. Carsin, et Y. Barrandon, « Long-term regeneration of human epidermis on third degree burns transplanted with autologous cultured epithelium grown on a fibrin matrix », Transplantation, vol. 70, $\mathrm{n}^{0} 11$, p. 1588-1598, déc. 2000. [6] F. Mavilio et al., « Correction of junctional epidermolysis bullosa by transplantation of genetically modified epidermal stem cells », Nat. Med., vol. 12, n 12, p. 1397-1402, déc. 2006, doi: $10.1038 / \mathrm{nm} 1504$.

[7] T. Hirsch et al., «Regeneration of the entire human epidermis using transgenic stem cells », Nature, vol. 551, no 7680, p. 327-332, 16 2017, doi: 10.1038/nature24487.

[8] N. A. Agrawal, D. Zavlin, M. R. Louis, et E. M. Reece, «Stem Cells and Plastic Surgery », Semin. Plast. Surg., vol. 33, no 03, p. 162-166, août 2019, doi: 10.1055/s-00391693018.

[9] M. M. Alexaline et al., «Bioengineering a Human Plasma-Based Epidermal Substitute With Efficient Grafting Capacity and High Content in Clonogenic Cells », Stem Cells Transl. Med., vol. 4, n 6, p. 643-654, juin 2015, doi: 10.5966/sctm.2014-0155.

[10] H. Green, O. Kehinde, et J. Thomas, « Growth of cultured human epidermal cells into multiple epithelia suitable for grafting », Proc. Natl. Acad. Sci. U. S. A., vol. 76, n ${ }^{\circ}$ 11, p. 5665-5668, nov. 1979, doi: 10.1073/pnas.76.11.5665.

[11] A. Cirodde, T. Leclerc, P. Jault, P. Duhamel, J.-J. Lataillade, et L. Bargues, « Cultured epithelial autografts in massive burns: A single-center retrospective study with 63 patients », Burns, vol. 37, $\mathrm{n}^{\circ}$ 6, p. 964-972, sept. 2011, doi: 10.1016/j.burns.2011.03.011.

[12] R. Sood et al., « Cultured Epithelial Autografts for Coverage of Large Burn Wounds in Eighty-Eight Patients: The Indiana University Experience », J. Burn Care Res., vol. 31, $\mathrm{n}^{\mathrm{o}} 4$, p. 559-568, juill. 2010, doi: 10.1097/BCR.0b013e3181e4ca29.

[13] M. Meuli et al., «A Cultured Autologous Dermo-epidermal Skin Substitute for FullThickness Skin Defects: A Phase I, Open, Prospective Clinical Trial in Children », Plast. Reconstr. Surg., vol. 144, nº 1, p. 188-198, 2019, doi: 10.1097/PRS.0000000000005746.

[14] D. Du Bois et E. F. Du Bois, «A formula to estimate the approximate surface area if height and weight be known. $1916 »$, Nutr. Burbank Los Angel. Cty. Calif, vol. 5, n 5, p. 303-311; discussion 312-313, oct. 1989.

[15] S. Hettiaratchy et R. Papini, « Initial management of a major burn: II — assessment and resuscitation », BMJ, vol. 329, $\mathrm{n}^{\mathrm{o}}$ 7457, p. 101-103, juill. 2004, doi: 10.1136/bmj.329.7457.101.

[16] A. B. Wallace, «THE EXPOSURE TREATMENT OF BURNS », The Lancet, vol. 257, no 6653, p. 501-504, mars 1951, doi: 10.1016/S0140-6736(51)91975-7.

[17] C. LUND, «The estimation of areas of burns », Surg Gynecol Obste, vol. 79, p. 352-358, 1944.

[18] J. G. Rheinwald et H. Green, «Serial cultivation of strains of human epidermal keratinocytes: the formation of keratinizing colonies from single cells », Cell, vol. 6, $\mathrm{n}^{\mathrm{o}} 3$, p. 331-343, nov. 1975.

[19] D. J. Williams et J. D. Walker, «A nomogram for calculation of the Revised Baux Score », Burns, vol. 41, n 1, p. 85-90, févr. 2015, doi: 10.1016/j.burns.2014.05.001. 
medRxiv preprint doi: https://doi.org/10.1101/2021.04.16.21255595; this version posted April 16, 2021. The copyright holder for this preprint (which was not certified by peer review) is the author/funder, who has granted medRxiv a license to display the preprint in perpetuity.

All rights reserved. No reuse allowed without permission.

[20] M. D. Cirillo, R. Mirdell, F. Sjöberg, et T. D. Pham, « Tensor Decomposition for Colour Image Segmentation of Burn Wounds », Sci. Rep., vol. 9, $\mathrm{n}^{\circ}$ 1, Art. ${ }^{\circ}$ 1, mars 2019, doi: 10.1038/s41598-019-39782-2.

[21] R. Alvo, K. Serror, R. Bern, M. Chaouat, M. Mimoun, et D. Boccara, « Alternative à la greffe de peau pour la couverture des brûlures profondes de la face dorsale de la main en aigu: revue de la littérature », Ann. Burns Fire Disasters, vol. 30, nº 4, p. 296-302, déc. 2017.

[22] J. Djian et al., «Photographie clinique par smartphone en chirurgie plastique et protection des données personnelles : développement d'une plateforme sécurisée et application sur 979 patients », Ann. Chir. Plast. Esthét., vol. 64, nº 1, p. 33-43, févr. 2019, doi: 10.1016/j.anplas.2018.06.005. 